[Penultimate DRAFT. Please Gite THE PUblished VERSION:

Philosophical Quarterly 65 (261): 711-731. 2015]

\title{
Personal Style and Artistic Style
}

\author{
Nick Riggle \\ University of San Diego
}

\begin{abstract}
What is it for a person to have style? Philosophers working in action theory, ethics, and aesthetics are surprisingly quiet on this question. I begin by considering whether theories of artistic style shed any light on it. Many philosophers, artists, and art historians are attracted to some version of the view that artistic style is the expression of personality. I clarify this view and argue that it is implausible for both artistic style and, suitably modified, personal style. In fact, both theories of style crack along the same line, which suggests that they can indeed be mutually illuminating. I articulate and defend a view of personal style according to which, roughly, having style is a matter of expressing one's ideals. I show how this illuminates the widely neglected value of personal style and propose a new, analogous theory of artistic style: artistic style is the expression of the ideals the artist has for her art.
\end{abstract}

\section{Introduction}

When we think about a person's style, we use either a descriptive notion or an evaluative one.

Descriptively speaking, a person's style is her way of doing things: of dressing, decorating, walking, gesturing, talking, and so on. The thought seems innocent enough. But we also think that not everyone has a style, that having a style is something to work at or achieve - we don't get it for free. If a person's style is just her way of doing things, then surely everyone who does things has a style, for every doer does things in some way or other. So does everyone have a style or not? There is a similar question about the evaluative notion of style. We tend to admire people who we think have style. We can admire their style, and we can admire them for their style. Yet, we also tend to think that the pursuit of style is not very important, that it is even frivolous or trivial - a pursuit of questionable value. Stephanie Ross's entry on style in the Oxford Handbook of Aesthetics begins by discussing apparent examples of personal style. She writes, "In all these cases, 
style seems somewhat trivial, its singleminded pursuit morally questionable, since those cultivating style may be neglecting 'deeper', more important concerns."' (Ross 2005) Why would we admire those who we think engage in trivial or unimportant pursuits? Is style valuable or not?

The signs point to the presence of confusion along both descriptive and evaluative lines.

We think that everyone has some style or other - it comes cheap and is of little interest; that style is developed or achieved and worthy of admiration, even emulation - only some people have it; and that although style is something to pursue or cultivate, its pursuit or cultivation is a trivial matter, perhaps even morally questionable.

To better understand personal style, then, we would do well to tease out these different strands of thought about it. Of particular interest is the thought that style is an achievement. If style is an achievement, then what sort of achievement is it? Is it something we have reason to care about from an ethical or moral point of view? What must one do, or be, to have the kind of style that could be worthy of admiration?

One way to approach these questions is to look to the relatively considerable literature on artistic style. Style in art is an achievement, arguably one of great value. And if one looks to the literature, there appears to be wide agreement about its basic contours. The poet Frank O'Hara tells us that "Style at its lowest ebb is method. Style at its highest ebb is personality." (O'Hara 2008) Arthur Danto echoes O’Hara when he favorably cites Buffon's famous lines about literary style: "Style," says Buffon, "is the man himself." Danto contrasts style with "manner" - a routine method of artistic production that lacks "spontaneity". The artist who relies on manner is distanced or "alienated" from who he really is - that is, from his style. Style is the man himselfhis "personality" — while manner is mere method. (Danto 1981) Personal style at its "lowest ebb",

${ }^{1}$ Of course, the singleminded pursuit of nearly anything is morally questionable, being, as it is, singleminded. That aside, the worry that the pursuit of style is morally questionable needs to be addressed, and I do so below ( $\$ 5$ ). 
then, is method or routine - just one's way of doing things; personal style at its "highest ebb" is personality. $^{2}$

These claims have the ring of truth, but it is unclear which part of them is resounding. Emphasizing personality, or "the man himself," doesn't help to answer the above questions. Nearly everyone has and expresses a personality, so why would we think that only some of them have a style? The descriptive question is unanswered. As is the evaluative question: our personalities are often expressed with almost no effort or reflection, so how could doing so be an achievement?

In spite of these concerns, I think that personal and artistic style can be mutually illuminating, but because the entrenched view of artistic style is mistaken. Once we see what is wrong with this view, reflection on personal style helps to correct it. I begin by reviewing this literature and arguing, against it, that artistic style is not the expression of personality (§2). I then argue that the same is true of personal style. The fact that both theories of style crack along the same line suggests that theories of artistic and personal style can indeed be mutually illuminating. I then develop a view according to which, roughly, personal style is the expression of ideals (§3). This illuminates the neglected value of personal style $(\S 4)$ and suggests a new theory of individual artistic style $(\S 5)$.

\section{Artistic Style as the Expression of Personality}

Discussions of artistic style often begin with a distinction between general style and individual style. ${ }^{3}$

According to Richard Wollheim, general style is a feature of artworks, and is associated with a set

\footnotetext{
${ }^{2}$ Arguably the most influential statement of the view is Jenefer Robinson's widely cited and much-anthologized "Style and Personality in the Literary Work," which I focus on below.

${ }^{3}$ Here and below I draw on Richard Wollheim's "Pictorial Style: Two Views" and on his remarks on style in Painting as an Art. Wollheim notes that the distinction between general and individual style is present in Wölfflin's Principles of Art.
} 
of distinctive characteristics - ones that generally group artworks together, or set them apart, in being particularly innovative, striking, or important. There are several common forms of general style, including "school" style, associated with a particular school; "period" style, associated with a certain historical time; and "cultural" style, associated with a particular culture. Rococo, for example, is a general period style, and we can point to various features of late baroque artflorid ornamentation, lively movement, asymmetrical patterns - that are characteristic of such works.

Wollheim claims that, whereas general style is located primarily in artworks, individual style is primarily a feature of the psychomotor character of individual artists. Individual artistic style is the style of the artist as an artist. Both notions of style are associated with sets of features in artworks, but if we fix the set of features, then the relation between the style and the set will differ in each case of style. In the case of general style the relation is supposed to be one of constitutionthe general style just is the set of features - while in the case of individual style, the relation is explanatory - the artist's individual style explains why his artwork has some of the features it has. ${ }^{4}$ (In what follows I will, hopefully innocently, use artistic painting and artistic painters as my main examples of artworks and artists.)

Individual artistic style is the style of the artist as such, but what exactly is the style of the artist as such? According to Wollheim, individual style is psychologically real, stable, and actionguiding. (Wollheim 1979; 1990: 25-36) The thought is that individual style is primarily a feature of the artist's psychology that plays a stable and guiding role in his artistic activity, giving his works (at least some of) their artistic character. In "Pictorial Style: Two Views," Wollheim explains in more detail what he thinks goes into the psychological reality of individual style. He introduces

\footnotetext{
${ }^{4}$ Wollheim argues for this point in several places. See for example, pp. 194-200 of "Pictorial Style: Two Views".
} 
the notion of a style process, which includes a set of schemata or concepts under which the artist's resources are brought, a rule for operating on the conceptualized resources, and a disposition to act on the rule.

Regarding the first element in a style process, individual style depends in part on the conceptual apparatus the artist brings to her work. What she can do depends in part on what she has the capacity to think she can do. This is true in spite of the fact that she can do things, artistically, without "thinking" (imagine an artist painting in a trance). For what matters is what she accepts as doable in her art. If she does not have the intellectual capacity to accept as her artwork the product of her unthinking activity, then it will never see the light of day. This in turn depends on a number of things: her experience, her knowledge of the history of art, and her ability to creatively imagine new ways of doing things.

So the artist must be able to think of something as an artistic resource, as something she can use to meet her artistic ends. The artist's schemata allow her to think of certain items as artistic resources - of paints, lines, brushstrokes, shading, and so on. They also allow her to formulate rules for acting on these resources as she understands them. For example, perhaps she thinks that outlines - a schematized resource - are to be avoided; that lighting should be uniform across the plane; that she should avoid bright colors and stick to earth tones; and that the edges of objects should be soft but defined.

Wollheim notes that an especially important type of rule for using artistic resources is an integrating meta-rule - a rule for coordinating the operation of the various first-order rules. "Such rules," he writes, "are important because they are probably the most significant agents in securing a characteristic that any one individual style must possess: that is, overallness or unity, where this is taken in a normative sense." (193) An (overly simple) integrating rule for the firstorder rules mentioned in the previous paragraph might be, roughly, The canvas should be simple and 
clean. The first-order rules are the artist's way of following this higher-order rule. Obviously, this particular set of rules seriously underdetermines the painterly results. But to get a sense of what might result, we can (fancifully) imagine that these rules played a role in Morandi’s style.

Unfortunately, Wollheim (admittedly) has little to say about the disposition to act on a rule. He just says it is a necessary condition of having individual style (193). But if style is a way of doing things - in this case, a way of painting - then the disposition to act is precisely what we need to know about. Without at least some general description of it and how it affects the activity of painting, we basically only understand the general kinds of activities and capacities that go into the art of painting. The artist conceives of something as a pictorial resource, finds a set of rules under which to operate on those resources, and is disposed to employ the rules. But style is largely in the choosing, in settling on doing things one way rather than another, or in settling on this technique rather than that. Without understanding what guides the artist in settling on a certain way of painting, we cannot understand the essence of individual style.

To make this a little more vivid, consider a person who has no artistic concepts and no rules for acting on artistic resources. One day, he goes to art school and receives a grueling training in painting: he learns about all of the available artistic concepts and resources relevant to painting and is trained in a breathtaking array of rules for acting on those resources. Before long, he is able to paint anything in a thousand different ways. Now imagine that none of these ways of painting appeal to him as a painter. Some appeal to him as an art student or art appreciator: he sees that some employ nice colors, some emphasize fine lines and subtle shading, others result in unique textures. But none speak to him as his way of painting - they are just different ways of painting. In other words, there is nothing in him that speaks to his painting one way rather than another, with any particular set of concepts and rules. To understand what individual style is, we need to know more about this aspect of its psychological reality. 
Ideally, we would have a way of filling in the following scheme:

Artistic Style An artist's work has individual style if and only if it is an expression of the artist's

Where the blank is occupied by something that is realized in the artist's psychology.

Arguably the most influential proposal on this score is Jenefer Robinson's proposal in "Style and Personality in the Literary Work". Robinson's guiding thought is the same as Wollheim's - individual style has some kind of psychological reality. In support of this, she cites the literary critic Ian Watt, in the context of a discussion of Henry James: "The most obvious and demonstrable features of James's prose style, its vocabulary and syntax, are direct reflections of his attitude to life and his conception of the novel." Robinson sets out to "explain and justify" Watt's claim. (228) She writes that, “...style is essentially an expression of qualities of mind, attitudes, interests, and personality traits which appear to be the author's own." ${ }^{\prime 5}$ The scope of her list of mental state types is extremely broad. It includes, in addition to qualities of mind, attitudes, interests, and personality traits, "character," "sensibility," "moral qualities," "and so on". This gives us a way of characterizing the relevant disposition to act as the disposition to perform those artistic acts that are expressive of, or that result in the expression of, the artist's "own” psychological states.

To make this more concrete, we need to clarify what Robinson means when she says that the mental state must be "one's own". The most familiar sense in which a psychological state is "one's own" is what we might call the thin sense, or the sense in which the state is part of one's psychological history. But some states that are owned in the thin sense are not owned in another

\footnotetext{
${ }^{5}$ Wölfflin (1950) claims that individual style is the expression of "temperament" (sometimes "personality"): "We shall realise that a certain conception of form is necessarily bound up with a certain tonality and shall gradually come to understand the whole complex of personal characteristics of style as the expression of a certain temperament." (6; see also page 10)
} 
sense: one might have a desire or think a thought that one does not wish to have or think. These are mental states that are not one's own in the sense that one does not "identify" with them. But some states do enjoy the further status of being states one identifies with - they are the states that one, in some sense, wants to have. Let's say that the mental states that enjoy this further status are "one's own" in the thick sense, while leaving open the question of what makes a mental state thick. ${ }^{6}$

Robinson does not employ the thick sense of ownership. She writes that, "In expression, as the word itself suggests, an "inner" state is expressed or forced out into "outer" behavior. An "inner" quality of mind, character or personality causes the "outer" behavior to be the way it is, and also leaves its "trace" upon that behavior." (229) Let's call this notion of expression simple expression. A mental state can be "simply expressed" whether or not it has the status of being endorsed or identified with. ${ }^{7}$

However, Robinson's sense of ownership is not just the thin sense. She restricts the set of style-relevant mental states further by claiming that they must be "standing" states, not ephemeral moods or passing emotions. She writes, "Only those properties which are "standing" or long-term properties can be considered stylistic. Thus stylistic qualities are likely to be qualities of mind, moral qualities and deep-seated character traits...”. (232) In this she agrees with Wollheim's view that style, as a feature of one's psychology, must be relatively stable. So Robinson's view requires a sense of ownership according to which a mental state is one's own if it is a thin, standing state.

\footnotetext{
${ }^{6}$ As long as the basic distinction is clear enough we can proceed. There is a substantial literature on mental state ownership and identification. The locus classicus is Frankfurt (1971); see also Frankfurt (1987). For excellent discussion of these issues see Bratman (2003).

${ }^{7}$ Robinson formulates a different theory of expression in her more recent work Deeper than Reason. See chapter 9 for her "New Romantic Theory of Expression”.
} 
There is a familiar sense in which a mental state is "one's own" if it is a thin, standing state. We think that a stable desire to eat burritos, or a stable preference for yellow, partly characterizes the kind of person one is. We think that a normally calm person who, one day, keeps getting angry at minor things "isn't being himself”. This holds even of states that one does not endorse, or even actively disavows. Consider a compulsive liar who feels strong, sometimes overwhelming, urges to lie, while wishing he were different. We understand if this person feels a certain amount of self-hatred or frustration. He dislikes who he is, which in this case is partly characterized by his standing, disavowed mental state.

Thus, a state might be "one's own" in a sense if it is a thin, standing state whether or not it is endorsed. This gives us a third sense in which a mental state is “one's own". Following Robinson, let's call the set of one's thin standing states one's personality. ${ }^{8}$ Thus, a state can be one's own in the thin sense, the thick sense, and the personality sense. The emerging view of individual style is the following. The general principle guiding stylistic activity is the expression of personality: individual artistic style concerns artistic activity constrained by the aim of expressing certain mental states, namely those that constitute the artist's personality, that is, his thin standing states. Filing in the scheme:

Artistic Style (Personality) An artist's work has individual style if and only if it is an expression of the artist's personality.

Although the view retains Wollheim's guiding thoughts, it cannot be right. ${ }^{9}$ An artist's individual style need not be an expression of his personality. We can easily conceive of

\footnotetext{
${ }^{8}$ Strictly speaking, this may not be exactly right. Perhaps the personality is better thought of as a proper subset of one's "standing" states.

${ }^{9}$ Some philosophers might object to Robinson's view on situationist grounds, according to which personalities so defined are rare at best, non-existent at worst. Whether or not that's right, Robinson can refine her view, as Aaron Meskin pointed out to me, by focusing on local traits that are salient primarily in artistic contexts. This refinement
} 
counterexamples: an artist who has the very opposite of a serene personality - neurotic and halfcrazed - might aim to and succeed in producing images that express pure serenity. The artist does not have a serene personality, so the picture cannot be an expression of his personality in the relevant sense. Such a view is also in tension with the powerful myth - present in Plato's Ion, and in Romantic ideology - according to which the artist creates in a half-crazed state of possession or inspiration. The artist sheds or dislocates his everyday personality and adopts another - one provided by the spirits or gods, or that expresses one's 'true self'. Flaubert's advice positively recommends the possibility: "Be regular and tidy in your life like a bourgeois, so you can be fiery and original in your work." 10

The aesthetics literature in general, and Robinson especially, is sensitive to such disconnections between the real personality of an artist and the "apparent personality" in his works. Robinson's example is the tension between Tolstoy's "querulous and intolerant" personality and the compassion and understanding exhibited toward the characters in Anna Karenina. The apparent personality of a work is the personality its author appears to have, judging from features of the work (and considering relevant background information). ${ }^{11}$

Robinson's influential response is to move to an account of style that fills in the scheme with the implied personality of a work - an account of literary style (which she thinks generalizes (pp. 228)) according to which the style of a literary work is identified with those of its features that express the personality of the apparent artist. ${ }^{12}$

\footnotetext{
is worth considering in more detail, though I think the view I develop below $(\$ 5)$ is more plausible. For a brief discussion of the refinement, see Meskin (2001: 449; 2009: 24-25).

10 "Soyez régulier et ordonné dans votre vie comme un bourgeois, ainsi vous pourrez être emporté et original dans votre œuvre." From Correspondance.

11 There is much discussion of this notion in the literature, which originated with Booth (1983). See chapter 6 of Robinson (2007) for fairly recent discussion.

${ }^{12}$ See Robinson (1985: 233-37). For a similar move and view see Walton (1979).
} 
But this move essentially gives up on the initial task, which was to give an account of the psychological reality of individual style. Robinson's account focuses instead on the character of artworks. But the fact that what is expressed in a work might not be the artist's personality does not motivate a move away from a psychologically robust account of style.

The problem can be brought out in a slightly different way. Our guiding thoughts were that style is a particular way of performing artistic acts, and the disposition to perform them in that way is grounded in large part in the artist's psychology. One proposal is that the stylisticallyrelevant disposition is to perform those acts that are expressive of personality. But this proposal does not work. So what's the most reasonable move? The logical space includes: (1) reject the proposal and look for a new one in line with our guiding thoughts; (2) reject the proposal and reject one of the guiding thoughts; or (3) reject the proposal and reject both of the guiding thoughts. The most reasonable move is clearly (1), yet Robinson's move is a way of opting for (3). But the disconnect between real and apparent personalities does not motivate rejecting either of the guiding thoughts. Thus, if individual style is psychologically real, then we lack a good account of it.

An addition to an account of the psychological elements of individual style is offered in Baxandall's Patterns of Intention and developed in Jonathan Gilmore's The Life of a Style. Central to Gilmore's theory is Baxandall's notion of a brief, which comprises "those representations a painter has about both the ends of his or her activity as a painter and the appropriate means to reach those ends.” (75) A brief is a type of complex representation- “...composed of beliefs, attitudes, desires, and so on..."- - whose content specifies the ends of a painter's activity as a painter and the means he must take to achieve those ends. ${ }^{13}$ Gilmore's view is that an artist's

\footnotetext{
${ }^{13}$ Wollheim's “schemata” seem to be flexible enough to include an artist's brief in this sense.
} 
individual style is expressed in the set of procedures and techniques he adopts and internalizes in order to realize his artistic ends, as represented in his brief. These are techniques “...that seem to respond to or fit with what those representations of means and ends require." (82)

But there's never a unique way to satisfy an artistic brief, so why does the artist settle on one set of techniques rather than another? This just restates the question posed to Wollheim concerning the stylistically-relevant disposition to act, and Gilmore's answer does not take us much further: "The artist's character or subjectivity is what responds to the requirements of the brief and gets expressed through the parameters of the brief.” (92) According to Gilmore, the artist's "character and subjectivity, along with the artist's body" are "what does the responding", with the result that individual style is an expression of "character and subjectivity," or of “the individual artist's self” (92, 96). But Gilmore does not specify “character and subjectivity” any further. It's either personality in Robinson's sense or something else, and we saw that personality does not work. But if it's something else, then we need an account of it. ${ }^{14}$

The nature of this problem, and its solution, come into sharper view when we consider the analogous problem in the theory of personal style. As I will argue, what it is in general for persons to have style sheds light on what it is in particular for artists to have style. Unfortunately, very little has been written about personal style, so I will begin by considering the strictly analogous view of artistic style just discussed, namely, that a person's style is his way of doing things, where the things that are "his way of doing things" are those that express his personality.

\footnotetext{
${ }^{14}$ Gilmore's book is mainly about general style, so a detailed theory of individual style is not on offer. Chapter 3 , however, contains a rich and illuminating discussion of individual style.
} 


\section{Personal Style: Personality and Ideals}

Personal style is rarely the object of philosophical attention, but when it is writers tend to express views remarkably similar to the views about individual style in art. ${ }^{15}$ Arthur Danto, for example, writes "...it seems to me that what we mean by style are those qualities of representations which are the man himself, seen from the outside, physiognomically." ${ }^{16}$ Although some writers don't use the notion of personality - preferring "the man himself" - the most straightforward way of making sense of this view is to say that personal style is the expression of personality, understanding personality just as we did above.

We can extract a view to this effect from Jenefer Robinson's brief discussion of personal style. According to Robinson, a person's style is his way of doing things, and "his" way of doing things is identified with those ways that are expressive of personality. "...[M]y style of dressing, working, speaking and making decisions is typically an expression of (some features of) my personality, character, mind or sensibility." (229) To assess the view, we can import the scheme from above:

Personal Style A person's action is her style if and only if it expresses her personality.

But like the analogous theory of artistic style, this theory of personal style cannot be right. There are clear counterexamples in both directions. Consider an impatient driver. She is easily and consistently upset by the slightest traffic. Her impatience is a thin, standing state, and her actions are expressive of this state. So her actions are expressive of her personality. But are her impatient actions thereby her style? They obviously are, if style is nothing more than "one's way of doing

\footnotetext{
${ }^{15}$ For some discussion of style Kennett \& Wolfendale (2011), which focuses largely on fashion but also a bit on style. See also chapter 3 of Nehamas (2007).

16 See Danto (1981: 207); see also Danto (1998).
} 
things." But our task is to make sense of the thought that style is an achievement. If we think of style as an achievement, then her impatient way of driving is not necessarily stylistic. People express their personalities in a number of ways that nonetheless seem insufficient for the achievement of style: a person's disavowed but persistent shyness at parties, neediness in relationships, or obsessive manner of housekeeping. If that's right then the expression of personality is not sufficient for personal style.

A response is to say that style is the expression of those features of personality that are one's own in the thick sense. Impatience, shyness, and so on are all features that people may dislike in themselves or even disown. Although I will argue that there is something right in this thought - style does have something to do with identification of a sort - the reply cannot save the theory because of a fatal problem: there is a sense in which the simple expression of personality is not necessary for personal style. Specifically, style may be a matter of expressing (in a sense to be determined) some state, M, where M does not figure in one's personality. For example, a person with a nervous and abrasive personality could, at a given time, "express" a calm and charming personality by way of having style; an overly sentimental person could "express" a gruff and aggressive style. Their personalities are neither calm and charming, nor gruff and aggressive, so their style is not a simple expression of their personalities. On the view I develop below, personality is expressed in style: style can mark and accentuate personality; and personality can be expressed in the contours and character of one's style, but it is not the primary aim of stylistic expression.

Yet something seems right about the view. At the very least, it is difficult to conceive of a person's style having nothing to do with self-expression of a sort. But if the "self" being expressed isn't necessarily one's personality, then what is it? 
In a striking passage from The Second Sex, Simone de Beauvoir suggests that style is the expression of something other than personality:

"Even if each woman dresses in conformity with her status, a game is still being played: artifice, like art, belongs to the realm of the imaginary. It is not only that girdle, brassiere, hair-dye, makeup disguise body and face; but that the least sophisticated of women, once she is "dressed," does not present herself to observation; she is, like the picture or the statue, or the actor of the stage, an agent through whom is suggested someone not there, that is, the character she represents but is not. It is this identification with something unreal, fixed, perfect as the hero of a novel, as a portrait or a bust, that gratifies her; she strives to identify herself with this figure and thus to seem to herself to be stabilized, justified in her splendor."17

De Beauvoir is describing a form of self-presentation that, in one crucial respect, contradicts that described by Robinson, Danto, and others. The dressed woman does not present herself to view; her way of dressing isn't the "outward and visible symbol" of herself. What matters is not so much the person one $i s$ but the person one, in some sense, strives to be. She further clarifies by adding that what matters is our "identifying" ourselves with an unreal "character". But we don't adopt just any characterological self-conception — we adopt a conception according to which we are "perfect as the hero of a novel". If we take this to be a remark about personal style, then it suggests that what matters in style is a conception of the kind of person one aspires to be. De Beauvoir seems to be describing the practice of aiming to express characteristics that we think are worth our embodying, by way of becoming, or perhaps continuing to be, the kind of person we aspire to be. Let's call these our "personal ideals" or "ideals" for short. (To be sure, such a practice can be severely distorted, and distorting, in a number of ways; de Beauvoir was critical of the form it took for women in mid-century French culture.)

It is potentially misleading to speak of "ideals" in this context. The notion of an ideal connotes perfection or positive value, but one's ideals (in my sense) might not be altogether positive. Someone might have as their personal ideal being scrappy and defiant, or carefree and

\footnotetext{
${ }_{17}$ De Beauvoir (1953: 533) (second emphasis added).
} 
spontaneous - traits that are potentially offensive, impolite, or risky. What matters is that the states be objects of aspiration, and we normally think of ideals as the formal objects of aspiration. But then it is easy to slide from something's being an ideal to its being a "perfection", virtue, or morally admirable trait. Of course, one regards one's ideals as positive in a sense, or as worthwhile pursuits. The person who aspires to be scrappy and defiant might understand that he can be offensive and impolite, but he idealizes scrappiness and defiance. So we should keep in mind that ideals are not necessarily perfections.

Our ideals can and tend to change over time - they wax and wane, become more or less salient to us. They can also conflict in various ways, practically with each other or with other aims that, in one way or another, we acknowledge or accept. Consider a father who is left alone to care for his child. He might (1) have ideals that conflict with single fatherhood - perhaps he aspires to live the spontaneous life of a cosmopolitan bachelor; (2) he might have ideals that are compatible with single fatherhood - that is, he might be able to pursue his aspirations and be a father without aspiring to be a father; (3) he might have ideals that support single fatherhood - he might aspire to be an upstanding guy and upstanding guys are good fathers; (4) he might have ideals that both support and conflict with fatherhood - he might aspire to be a father and a rock star; (5) he might have ideals that conflict with his personality, or with values he has accrued over time, perhaps through his family or wider culture - he "places value on" being a father, but aspires to do something that conflicts with it. So personal ideals don't necessarily cohere with one another or with other concerns a person has.

De Beauvoir's suggestion, as we're reading it, is that style is the expression not of our personality, but of our ideals. But what is the relation, if any, between our personality and our ideals? Personality can both feature in and constrain our ideals. First, personality can feature in our ideals. We might ideally be some way we actually are. These are features of our "best self"; they 
are features we aspire to continue having or cultivating. Secondly, personality is a constraint on which, and how many, ideals we can have. For some people it might be psychologically impossible to aspire to certain ideals; and for some it might be normatively inappropriate to adopt certain ideals. Even if it is psychologically possible for a shy person to aspire to be a social butterfly, it might not be an ideal worth her adopting. A person's ideals should take into account her natural dispositions, physiology, and motivational set. This does not mean that none of her ideals can conflict with her personality, but it does mean that they cannot all conflict.

Thus, personality and personal ideals are closely related. This supplies us with a diagnosis of the view that style is the expression of personality. Intuitively personal style is self-expression of a sort, but who we take ourselves to be - the self we aim to express - could be a conception of ourselves as we actually are, or it could be a conception of ourselves as defined by our ideals. It is easy to confuse our personality with our ideals because those aspects of personality that we aspire to cultivate are, ipso facto, among our ideals.

With this in place, let's swap Robinson's notion of personality with our notion of ideals.

Personal Style (Ideals) A person's action is her style if and only if it expresses her ideals. The problem with simply importing the scheme from above is that the notion of expression we have used thus far is no longer appropriate. What is it to express an ideal, particularly when the characteristic that is "expressed" does not feature in one's personality? Recall that the simple notion of expression involves the idea of an inner state, M, causing - being pressed out into- $\mathrm{M}$ behavior. But my calm way of $\phi$-ing might issue not from any actual calmness, but from my ideal of being a calm person. So if our ideals are expressed at all, they aren't simply expressed. 
Let's think about what we do when we embody our ideals. ${ }^{18}$ Then if it makes sense to call such action an expression of those ideals we may do so. Perhaps the simplest proposal about action-by-ideal is to say that ideals are conceptions of people (real or not) we wish to resemble; our desire to resemble them motivates behavior we take to be characteristic of them, in conjunction with various beliefs we have about how to achieve the resemblance. But as J. David Velleman notes, such a view construes the motivational force of ideals as issuing from a desire to resemble. This has the consequence that one's ideal-motivated behavior will always fail to resemble the ideal, for the kind of person one wants to resemble is not motivated by a desire to resemble - she's the real deal. ${ }^{19}$

Velleman's alternative model begins with the thought that we need to make use of the imagination, not just of desires to resemble and beliefs about how to go about it. (Recall de Beauvoir's suggestion that style "belongs to the realm of the imaginary.") On Velleman's view, having and acting on an ideal involves imagining being the kind of person we idealize, and our imaginings play a role in our enacting the fiction that we are such a person. We regard ourselves inaccurately as being our ideal — say, as being a kind person - and under the aegis of fiction we act out the pretense. Another way the imagination might play a role in action-by-ideal is via metaphor. On this view, action-by-ideal involves regarding ourselves metaphorically as the kind of person we ideally are. The metaphor functions to draw our attention to the ways in which we are like our ideal and to thereby motivate action. ${ }^{20}$

\footnotetext{
18 "Embody" is my generic term for success in acting to realize an ideal. Such a generic term is useful because what success amounts to depends on what action-by-ideal consists in. I present two options below. ${ }_{19}$ Unless of course one idealizes resemblers, but then the problem iterates. See Velleman (2006).

${ }^{20}$ In my unpublished manuscript, "Ideals as Metaphors," I develop the latter view. For the purposes of this discussion the the views are on a par (and I don't assume they are the only possible views). For an account of the difference between metaphorical and fictional imagination, see Camp (2009).
} 
Both views of action-by-ideal entail that there may be a mismatch between what is embodied (e.g. kindness) and what does the embodying (e.g., the ideal of being a kind person). Both views, therefore, capture the earlier point that a nervous or overly sentimental person could embody a calm or aggressive personality by way of having style. Both views also entail that, when we embody our ideals, much is expressed in the simple sense, including aspects of personality. One's personality and physiology will inflect the way one's ideals are embodied and may be revealed through this inflection. For example, a nervous person (because of her nervousness) may embody her ideal of being a philosopher differently than does a cool and collected person. This goes the other way as well—one's non-ideal actions can be inflected by one's aspirations. A tough guy's ideal of kindness may temper and color his tough guy actions. This shows that (1) one's ideals need not be embodied perfectly or fully to influence action; and (2) in action-by-ideal much of ourselves, including our personalities, will be expressed in the simple sense. ${ }^{21}$

But is there a sense in which we express our ideals when we embody them, by acting on either a fictional or metaphorical self-conception? Consider a minimal notion of style:

Minimal Style A person's action is her style if and only if it embodies her ideals.

This is a very minimal notion - even the most subtle or fleeting action would be a person's style, if it embodies her ideals. One reason for favoring this minimal conception is that we are occasionally struck by the style of the slightest gesture or subtlest look - a well-timed smile, or the way someone sits - and even our own movements, postures, or feelings may strike us as our style in virtue of the way they seem to fit our ideal self.

\footnotetext{
${ }^{21}$ Thus, there is a sense in which expression of personality is necessary for personal style, insofar as personality is inevitably expressed when we go in for action-by-ideal. But this is not the same sense denied above, according to which there is a direct connection between what is expressed (e.g., calmness) and what does the expressing (e.g., the state of being a calm person). Thanks to an anonymous referee for pressing me to clarify this point.
} 
Yet an agent may embody an ideal (e.g., of calmness) without communicating that it is an ideal of hers. And perhaps what matters in style is that we accurately present ourselves as having certain ideals, by making salient the character of our actions in a way that highlights the fact that we value them as having this character. This would involve, among other things, knowledge of and attention to what would elicit the appropriate attention and recognition of others, including knowledge of certain conventional signals: serial action in the right circumstances (e.g., being consistently perceptive and caring), spontaneity of response (e.g., being spontaneously perceptive and caring), personal dress and décor (e.g., clothing and design that suggest warmth, generosity, and attention to detail). Success would mean that one's "empirical persona" or self-presentation reflects one's ideals. ${ }^{22}$ A more robust notion of style, then, would include communication or presentation:

Presentational Style A person's action is her style if and only if it embodies and communicates her ideals.

If either embodying or communicating one's ideals is expressive of those ideals, then style is the expression of ideals. Intuitively, the communication of ideals is sufficient for the expression of those ideals, but some theories of expression entail that the action must merely clarify for the agent what her ideals are. ${ }^{23}$ If embodying ideals is sufficient for that, then minimal style alone is an expression of one's ideals.

Yet even if neither embodiment nor communicative embodiment is sufficient for the expression of ideals, there is a sense in which the final end of action-by-ideal is the simple expression of our ideals. We go in for action-by-ideal with the aspiration of being a certain kind

\footnotetext{
22 See Goffman (1959) for a detailed study of self-presentation.

${ }^{23}$ See Collingwood (1958), chapter 6, for such a view. Collingwood restricts his discussion to the clarification of emotion, but I see no reason why he couldn't include ideals. Thanks to Robert Hopkins for suggesting this.
} 
of person. The more successful we are in embodying our ideals, the more our patterns of

behavior and response will reflect our ideals; the gap between our ideal selves and our

personalities will thereby shrink, and the larger our "best self" will become. If, in the end, our

ideal selves are exhausted by our best selves, then stylistic action will be a simple expression of

both ideals and personality. Our style really will just be our way of doing things, not as a simple

result of the fact that we are doers, but as a result of the fact that we are imaginative agents - and

that's an achievement.

\section{The Value of Personal Style}

On the view just articulated, personal style is not just a matter of exhibiting a good or valuable trait or even of exhibiting a trait that one judges to be good or valuable. Suppose one is hospitable and warm, and even judges being such to be good. If warmth and hospitality are not among one's ideals, then one doesn't thereby have style. There are a number of ways we might act that are moral, socially accepted or encouraged, gratifying, useful, admirable, or enviable: they are stylistic just in case they are expressive of one's ideals. It follows that merely acting in accord with a certain image is not sufficient for style; the image must reflect one's ideals. This is where posers fall short - they succeed at best in presenting their ideal of having certain ideals. ${ }^{24}$

\footnotetext{
${ }^{24}$ This suggests a fun point in favor of this theory of style: we can use the notion of presentational style to make sense of canonically stylistic figures. If style is among the ideals that feature in a person's style, then that person is either a dandy (/quaintrelle) or an aesthete. The dandy is someone whose sole ideal is that of having style. So, the dandy is someone who strives to present his ideal of presenting his ideals. This is clearly an empty pursuit. The dandy is "style" without substance. The aesthete, on the other hand, is someone whose values are not limited to having style - he is a poet, doctor, athlete, vagabond — but in addition, he has the ideal of presenting his nonstylistic ideals. The aesthete cares about making his life a presentation of his (largely non-stylistic) pursuits. Like the dandy, he wants style to pervade his life, but for him this is a grand expression of extra-stylistic ideals. Of course, these definitions are more theory-guided stipulation than analysis - the terms 'dandy' and 'aesthete' are used in extremely different ways.
} 
Yet the poser might superficially look exactly like the real deal. Having style is not just a matter of having a certain look. Two people can "look the same" but can be such that (a) they have different styles, or (b) at most one of them has style. Imagine a businessman in a grey twopiece suit, light blue dress shirt, and black shoes, and suppose that this way of dressing expresses a generic businessman's ideals: clean, confident, a team player, attentive to detail, and so on. It does not follow that he has style, for he might have different ideals. Relatedly, the view allows us to distinguish between being fashionable, having style, and adopting a fashion as one's style. To be fashionable is to adopt fashion-world looks; ${ }^{25}$ in its honorific sense, to be fashionable is to tastefully adopt fashion-world looks. To adopt a fashion as one's style is to adopt a fashionworld look either because the look expresses one's ideals or because being fashionable is among one's ideals.

Style is a matter of making one's actions and appearance an expression of one's ideals. Formulating and embodying ideals is a challenge, and presenting them requires consideration of the range of ideals others can recognize and how they can recognize and respond to them. This is one source of the value of personal style: it concerns the pursuit of ideals that, to no small extent, define the kind of life one thinks is worth one's living. Of course, one might have got it wrongone might have been attracted to bad ideals, or pursued good ones in the wrong way. But this type of pursuit is hardly trivial or superficial.

Is there another way to motivate the worry that personal style is unimportant or trivial, or that in pursuing it we neglect more important concerns? One might think that the superficial, or at least suspect, dimension of style concerns its presentational register - that is, presenting one's ideals in action, décor, dress, and other style-relevant media. Even if we agree that minimal style

\footnotetext{
25 This theory of being fashionable is developed in Farennikova \& Prinz (2011).
} 
has value, we might not agree that there is value in presenting one's ideals. We might even think that doing so has negative value, that it too easily risks being boastful, overbearing, ostentatious, or showy - in short, that it competes with morality.

It would be troubling if the pursuit of style conflicted in some way with morality. But nothing I have said requires that the ideals one adopts be non-moral. Having moral ideals is compatible with having style. In fact, something quite a bit stronger seems true: if one has moral ideals, then expressing those ideals is the default obligation. In other words, if one has moral ideals, then, other things being equal, one ought to have style. Consider manners and etiquette. ${ }^{26}$ Suppose that being polite requires one to present the image of a polite person even when, if one were to express one's personality, one would laugh or express distaste. If being polite is among one's ideals, then one thereby has style. Now consider people who have more robust moral ideals - those who, say, aim at moral sainthood, or Aristotelian or Confucian virtue. They don't just aim to be moral agents, they strive to be moral exemplars, and as such they aim to present themselves as that which they exemplify, namely, as those who live by moral ideals. Style, then, is at least compatible with morality and may even be required by it. ${ }^{27}$

But many people are not committed to being exemplars in this way, even if it is sometimes morally pressing to be one. So why think that the self-presentational side of style is more generally valuable?

I want to focus on an aspect of its value that is also present in artistic style. I think the pursuit of presentational style can clarify and solidify our ideals, by presenting them to ourselves

\footnotetext{
${ }^{26}$ Of course one might not think that manners, and the rules of etiquette that subserve them, are strictly governed by morality. For a lucid argument that they are, see Stohr (2011).

27 Of course some situations might require that one not be exemplary. The default obligation can be overridden. The general thought that morality demands attention to appearance has been a recent topic of several excellent papers in moral philosophy. See for example, Driver (1992) and Buss (1999). This is also a concern of Ancient moral philosophy, East and West: see Sherman (2011) and Olberding (2007).
} 
and others. Consider the following passage from John Williams's novel Stoner (1965), which tells the story of William Stoner, an unassuming and plain man, a mediocre English professor who grew up on a mediocre farm. At one point he buys a house he can't afford under pressure from a wife who doesn't like him. They move in, and he decides to turn a downstairs room into his study:

As he worked on the room, and as it began slowly to take a shape, he realized that for many years, unknown to himself, he had had an image locked somewhere within him like a shamed secret, an image that was ostensibly of a place, but which was actually of himself. So it was himself that he was attempting to define as he worked on his study. As he sanded the old boards for his bookcases, and saw the surface roughness disappear, the gray weathering flake away to the essential wood and finally to a rich purity of grain and texture - as he repaired his furniture and arranged it in the room, it was himself that he was slowly shaping, it was himself that he was putting into a kind of order, it was himself that he was making possible. (pg. 100-101, my emphasis)

In arranging the room, Stoner identifies with a certain image of himself - an image somehow reflected in or evoked by his experience of the emerging study. The passage suggests that this image is not a faithful self-image. It's an image "ostensibly of a place" that is "actually of himself'. It is a self-image that captures a kind of person Stoner wishes to be but currently isn'tit is an ideal that he had forgotten, repressed, or lost touch with and "locked away like a shamed secret". Stoner's arrangement and contemplation of the room returns the ideal to his awareness. Finding this ideal reflected in the room clarifies for Stoner what his ideals are, and this puts him "into a kind of order". ${ }^{28}$

Presentational style can clarify and solidify our ideals by creating opportunities to notice, respond to, and appreciate them. Consider the fact that it is common, and we tend to think worthwhile, for communities to present their ideals in public, through architecture, various forms of public art, and environmental design. Intuitively, publicly presenting these ideals reinforces the communal bonds that bring and keep a group together. If the presentational side of style is an

\footnotetext{
${ }^{28}$ Perhaps this helps makes sense of de Beauvoir's suggestion that style "stabilizes" the agent.
} 
individual-scale version of this, then it would seem to inherit the value the general case enjoys. So

how can personal style have such value? How can it form bonds and sustain connections?

Consider this passage from J. David Velleman. We all desire to be loved, a desire that:

“...one's own rendition of humanity, however distinctive, should succeed in communicating a value that is perfectly universal. (In this respect, it's like the desire to be found beautiful.) One doesn't want one's value as a person to be eclipsed by the intrinsic value of one's appearance or behavior; one wants them to elicit a valuation that looks through them, to the value of one's inner self." 29

As a result, "Whether someone is lovable depends on how well his value as a person is expressed or symbolized for us by his empirical persona." 30 As I have argued, the presentational side of personal style is a matter of making one's empirical persona an expression of one's ideals, and we take our ideals to capture the self we would be at our best. If love is ever a response to a person's value made manifest, then love can be a response to a person's style. The pursuit of style, then, can be an expression of the desire to be loved, by others and by oneself.

\section{Individual Artistic Style: A New Proposal}

Artists are like persons with style in the following way: they develop and present ideals in their work - but the ideals they present are artistic ideals, or ideals they have for their art. Now recall Wollheim's thought that individual style is a feature of the artist's psychology that plays a stable and guiding role in his artistic activity, giving his works (at least some of) their distinctive character. In $\S 2$ we located a problem with the view that individual artistic style is the expression of personality. The problem was that an artist might adopt a style that does not express her personality. Roughly, a shy and reserved person might be a passionate and lively painter. We found an analogous problem with an intuitive theory of personal style and argued that the

\footnotetext{
${ }^{29}$ Velleman (1999: 107).

${ }^{30} \mathrm{Ibid}$.
} 
solution was to understand personal style as a matter of expressing one's ideals. The theory of personal style locates a feature of the person's psychology that can play a stable and guiding role in his personal activity, giving his actions (at least some of) their distinctive character. Taking a clue from this theory, then, we can see that the literature on artistic style does not address the artistic analogue of a person's ideals - the ideals the artist has for her art. Filling in the scheme one last time:

Artistic Ideals An artist's work has individual style if and only if it is an expression of the ideals the artist has for her art.

Appeal to artistic ideals solves the problem raised in $\S 2$, while conserving the guiding thoughts initially set out by Wollheim. If the artist is expressing artistic ideals that come apart from or even conflict with her personality, then it should be no surprise that the artistic expression of such ideals is not necessarily the artistic expression of personality.

The artist who has or is developing an individual style must ask herself not just whether the application of some technique "looks good" in a generic sense, or solves whatever artistic problems concern her (i.e. answers her "brief"), but whether a certain way of painting expresses her artistic ideals. If that's right, then individual artistic style isn't just a matter of choosing some set of techniques to employ; it is a matter of discovering and developing the techniques that express one's ideals. But just as in personal style, the artist might not know what techniques those are until he tries them out in practice. The artist has to develop a style - it's not merely a matter of picking up a brush and finding out how, in fact, he paints - though to be sure, just as in personal style, the artist's personality and natural physiology are important contributing factors. Like Stoner's arrangement of the study, the artist may have to arrange her materials until something strikes her as her style, that is, as finally expressing her ideals. As a result, in art as in life 
many of the discoveries will happen upon reflection on the results of one's activity, or, once presented, in response to the love or encouragement (or lack thereof) of friends and critics.

An artist's artistic ideals can function as a higher-order integrating rule of the kind that Wollheim emphasizes. The simplistic rule that we previously imagined Morandi employing was The canvas should be simple and clean. To make explicit its function as an artistic ideal, we might write the rule as, "As an artist, my canvases must be simple and clean," where the "must" expresses the artist's resolve for his art to express a kind of clean simplicity. Such integrating rules can play a role in a range of artforms. To briefly discharge an early assumption, the account is apparently flexible enough to handle other visual arts and even non-visual arts like poetry and literature. A novelist might have certain integrating ideals as a writer, e.g. to be bold, spare, perceptive, or compassionate. Literary style, on this view, consists in the expression of these literary ideals, which will manifest in the way a character is drawn, a plot developed, or a scened depicted.

But in literature, as in art generally, an artist's artistic ideals may or may not diverge from her non-artistic ideals. Tolstoy may not have been as understanding in real life as he was toward his characters in Anna Karenina. Our ideals can conflict, and sometimes they should. Thus the character of an artist's self-expression may vary depending on whether or not he is making art. Critics were surprised to see Manet dressed like a bourgeois gentleman in Fantin-Latour's 1867 portrait. They figured that whoever would so blatantly disregard artistic tradition must do so in dress, too. But if the view developed here is right, then it shouldn't be much of a surprise. Manet could have had rather different aims in his personal style. Who knows, maybe he listened to Flaubert.

Of course, whether this view of artistic style is right requires more work - I have merely motivated and described the theory. A more detailed treatment would need to address several basic questions: What features can figure in an artist's style? Across what range of media and 
genre can a single style be manifested? What is the relation between artistic achievement and artistic style? How should we characterize the normative force of style? Is the value of individual style a kind of aesthetic value? If so, then how should we think of aesthetic value to account for this? I believe that the theory presented here has compelling answers to these questions, but showing that it does is a task for another time..$^{31,32}$

\section{BIBLIOGRAPHY}

Baxandall, Michael. (1985) Patterns of Intention: On the Historical Explanation of Pictures, Yale University Press

Booth, Wayne. (1983) The Rhetoric of Fiction, $2^{\text {nd }}$ Edition, University of Chicago Press

Bratman, Michael. (2003) “A Desire of One's Own," The Journal of Philosophy, Vol. 100, No. 5., pp. 221-42

Buss, Sarah. (1999) “Appearing Respectful," Ethics 109: 795-826

Camp, Elisabeth. (2009) "Two Varieties of Literary Imagination: Metaphor, Fiction, and Thought Experiments," Midwest Studies in Philosophy, XXXIII, 107-130

Collingwood, R.G. (1958). The Principles of Art. Oxford University Press

Danto, Arthur. (1981) The Transfiguration of the Commonplace, Harvard University Press

- (1998) "The Naked Truth," in ed. Jerrold Levinson Aesthetics and Ethics: Essays at the Intersection. Cambridge University Press

de Beauvoir, Simone. (1989) The Second Sex. Vintage

\footnotetext{
${ }^{31}$ In our manuscript, "Artistic Style as the Expression of Ideals," Robert Hopkins and I develop the view in much more detail and compare it to two versions of the personality view.

32 Numerous conversations with friends and colleagues had an influence on this paper. Special thanks to Paul Boghossian, Robert Hopkins, Andrew Huddleston, Béatrice Longuenesse, Derek Matravers, Aaron Meskin, Richard Moran, Jeff Sebo, Jack Spencer, Robert Stecker, J. David Velleman, the audience at the 2013 British Society of Aesthetics Annual Meeting, and two anonymous referees.
} 
Driver, Julia. (1992) “Caesar's Wife: On the Moral Significance of Appearing Good," The Fournal of Philosophy, 89:331-43

Farennikova \& Prinz. (2011) "What Makes Something Fashionable" in Fashion: Thinking with Style, ed. Jessica Wolfendale and Jeanette Kennett, Wiley

Flaubert, Gustav. Correspondance

Frankfurt, Harry. (1971) "Freedom of the Will and the Concept of a Person," The fournal of Philosophy, Vol. 68, No. 1

- (1987) "Identification and Wholeheartedness," in Ferdinand David Schoeman (ed.), Responsibility, Character, and the Emotions: New Essays in Moral Psychology. Cambridge University Press

Gilmore, Jonathan. (2000) The Life of a Style: Beginnings and Endings in the Narrative History of Art. Cornell University Press

Goffman, Erving. (1959) The Presentation of Self in Everyday Life, Anchor Books

Hopkins, Robert \& Riggle, Nick. (manuscript) "Artistic Style as the Expression of Ideals"

Meskin, Aaron. (2001) "Style," in Berys Nigel Gaut \& Dominic Lopes (eds.), The Routledge Companion to Aesthetics. Routledge

- (2009) "Authorship," in Paisley Livingston \& Carl Plantinga (eds.), The Routledge Companion to Philosophy and Film. Routledge

Nehamas, Alexander. (2007) Only a Promise of Happiness: The Place of Beauty in a World of Art. Princeton University Press

O’Hara, Frank. (2008) “Personism: A Manifesto,” in Selected Poems by Frank O'Hara, ed. Mark Ford. Knopf

Olberding, Amy. (2007) "The Educative Function of Personal Style in the Analects," Philosophy East and West, vol. 57, no. 3, pp. 357-374

Riggle, Nick. (manuscript) "Ideals as Metaphors"

Ross, Stephanie. (2005) "Style in Art," in the Oxford Handbook of Aesthetics, Oxford University Press

Robinson, Jenefer. (1985) "Style and Personality in the Literary Work," Philosophical Review, Vol. 94, No. 2

(2007) Deeper than Reason, Oxford University Press 
Sherman, Nancy. (2011) "The Look and Feel of Virtue," in Virtue, Norms, and Objectivity: Issues in Ancient and Modern Ethics, edited by Christopher Gill, Oxford University Press

Stohr, Karen. (2011) On Manners. Routledge

Velleman, David. (1999) "Love as a Moral Emotion," Ethics 109: 338-374 and collected in Self to Self

— (2006) "Motivation by Ideal," in Self to Self, Oxford University Press

Walton, Kendall. (1979) "Style and the Products and Processes of Art," in The Concept of Style, ed. Berel Lang. Cornell University Press

Wölfflin, Heinrich. (1950) Principles of Art History. Dover Publications

Wollheim, Richard. (1979) "Pictorial Style: Two Views," in The Concept of Style, ed. Berel Lang. Cornell University Press

(1990) Painting as an Art. Bolingen 